\title{
REVISITING SHINGO'S STRUCTURE OF PRODUCTION: AN ECONOMIC APPROACH BASED ON RAPID CAPITAL CIRCULATION
} GOMES, RODRIGO F.S. ${ }^{1}$,ANTUNES JR., J.A.V. ${ }^{2}$ \& LACERDA, DANIEL. P $^{3}$

${ }^{1}$ Ph.D. Candidate in the Graduate Program of Production and Systems Engineering. Permanent Researcher of Research Group on Modelling for Learning (GMAP). Unisinos University. São Leopoldo, Brazil

${ }^{2}$ PhD Researcher, Consultant and Professor Faculty Member in Post-graduation Program in Industrial Engineering and Systems - PPGEPS. Member of GMAP - Researching Group in Modelling for Learning. Unisinos University. São Leopoldo, Brazil

${ }^{3}$ PhD Researcher and Associate Professor in Post-graduation Program in Industrial Engineering and Systems - PPGEPS. Coordinator of GMAP - Researching Group in Modelling for Learning. Unisinos University. São Leopoldo, Brazil

\begin{abstract}
Productivity gain in industrial firms has been one of the most relevant challenges since the postwar period. Considering quality and organizational efficiency as essential requirements of global competitiveness, the structure of production model developed by Ohno and Shingo at Toyota Motor Co. still prevails as a reference for an increasing number of companies. This article aims at recovering the fundamentals of the Production Function Mechanism (PFM) proposed by Shingo in 1945, correlating it with the economic bias of capital circulation. Although PFM has had a direct influence on the intrinsic development of Toyota Production System (TPS) and later on the foundations associated with Lean, it's often not adequately referenced throughout the Production Engineering literature. The contribution of this work is associated with the theoretical discussion of the PFM, exploiting its economic impact through an empirical case. The study was conducted from a theoretical perspective throughout the literature review and an empirical single-case was employed to demonstrate the impacts on Cash Conversion Cycle (CCC) - a recognized metric for capital circulation. The results demonstrate that reducing lead time by improving the structure of productionbased on the PFM, contributes directly to a faster circulation of capital.
\end{abstract}

KEYWORDS: Structure of Production, Production Function Mechanism, Shingo, Toyota Production System,

\footnotetext{
${ }^{1} \mathrm{Ph} . \mathrm{D}$. Candidate in the Graduate Program of Production and Systems Engineering. Permanent Researcher of Research Group on Modelling for Learning (GMAP). Unisinos University. São Leopoldo, Brazil.

ORCID: https://orcid.org/0000-0003-3180-8726

Mail: rodrigofrank@edu.unisinos.br

Mobile: +55 $5199883-8273$
}

Corresponding address: Av. Unisinos, 950. CEP: 93022-750. São Leopoldo. Rio Grande do Sul, Brazil

${ }^{2} \mathrm{PhD}$ Researcher, Consultant and Professor Faculty Member in Post-graduation Program in Industrial Engineering and Systems - PPGEPS. Member of GMAP - Researching Group in Modelling for Learning. UnisinosUniversity. São Leopoldo, Brazil.

ORCID: https://orcid.org/0000-0002-9402-8666.

Mail: junico@unisinos.br

${ }^{3} \mathrm{PhD}$ Researcher and Associate Professor in Post-graduation Program in Industrial Engineering and Systems - PPGEPS.

Coordinator of GMAP - Researching Group in Modelling for Learning. UnisinosUniversity. São Leopoldo, Brazil.

ORCID: https://orcid.org/0000-0002-8011-3376.

Mail:dlacerda@unisinos.br 
Cash Conversion Cycle, PFM, CCC \& Capital Circulation

Received:Jun 05, 2020; Accepted:Jun 25, 2020; Published:Jul 13, 2020; Paper Id.: IJMPERDJUN2020336

\section{INTRODUCTION}

About thirty years after the publication of The Machine That Changed the World (WOMACK; JONES, ROOS, 1990), the production system model employed by Toyota Motor Co.- the seminal basis for the Lean concept, remains a reference for organizations in their quest for higher operational efficiency, quality, and economic results. Patterns of quality and efficiency required by the global market competitiveness turns the structure of production model developed by Ohno and Shingo at Toyota Motor Co. into a desired choice for many companies. However, the lack of theoretical understanding of the Production Function Mechanism (PFM) and the Toyota Production System (TPS) fundamental principles, such as Just In Time and Autonomation, weakens the implementation of the production model described by Ohno (1988), making it superficial and without effective results, as stated by Hines, Taylor and Walsh (2018).

Even though it had a profound influence on the development of the Toyota Production System (TPS), the Production Function Mechanism (PFM) has been not much referenced in national or international journals. An analysis of the Scopus Elsevier database shows that in the last 10 years Shingo concepts in the literature are mostly associated with SMED. However, Shingo's contributions go way beyond his proposed Single Minute Exchange of Die method and his principles are still playing an important role to industrial companies (KELLY; HINES, 2019).

Shingo $(1981 ; 1986 ; 1988)$ in a divergent approach to the Western concept, characterized the structure of production in an orthogonal network of Processes and Operations, in which flows differ when observed the production in time and space. While the Process Function is responsible for analyzing the work object (raw material) in time and space, the Operation Function focuses on the work subject (personnel, machines, or equipment) also in time and space. The theory of the Production Function Mechanism (PFM) was based on this approach, highlighted by Shingo (1981) as a knowledge without which it is not possible to correctly understand the Toyota Production System. Antunes Jr. (1994) and Ghinato (1996; 1998) reinforces the importance of Shigeo Shingo's theory for the improvement of production systems through the focus on Process Function.

This article aims at recovering the fundamental concepts of the Production Function Mechanism (PFM) initially proposed by Shingo in 1945, correlating it with the economic bias of capital circulation through an empirical case.The research was designedbased on the following methodological approach: (i) a literature review to recover the fundamental theory of the Production Functional Mechanism; (ii) an empirical case employed to illustrate how the PFM theory can affect the Cash Converting Cycle; (iii) a mathematical model is proposed to demonstrate the quantitative results.

This article is structured in 5 sections. Section II revisits the fundamental concepts of the Production Function Mechanism theory. Section III presents a discussion of PFM based on anempirical example. Results and discussions are covered inSection IV. Section V brings the conclusion, research limitations, and future work suggestions.

\section{LITERATURE REVIEW}

\subsection{Revisiting the Production Function Mechanism: aNetwork of Processes and Operations}

A distorted view of the connexions between processes and operations is often observed in the Western-American concept that defines "process" as a simple set of operations.Mathematically for this approach, as shown in equation 2.1 , the 
productive system $S_{p}$ can be defined as a function of the process, $f\left(P_{i}\right)$ which in turn is described as a set of operations $\left\{O_{i}\right\}$ observed over time.

$$
S_{p}(t)=f\left(P_{i}\right)=\left\{O_{j}\right\}, i, j=1,2 \ldots, n
$$

Shingo (1988) points out that the difference between Western production philosophy and the Japanese one belongs at the lowest level, in the conceptual starting points of the two approaches. According to Antunes Jr. (1994), the concepts of "Process" and "Operation" in the West are imagined as belonging to the same axis of analysis, i.e. they do not differ and reflect a linear correlation, so the performance of operations linearly influences of the process. Figure 1 presents a hypothetical diagram of this approach.

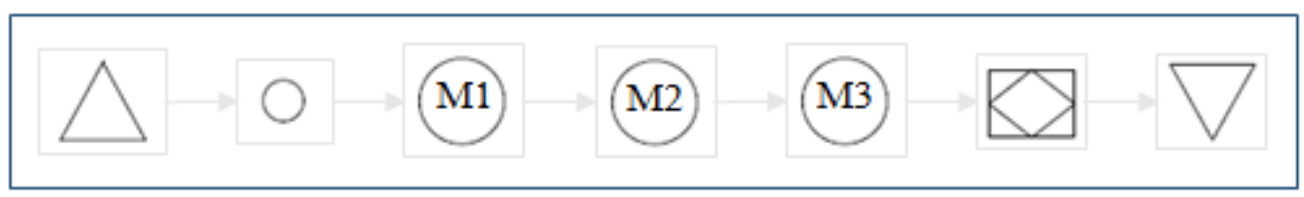

Figure 1: Western approach to the Production Function. Elaborated by the authors.

According to Figure 1, the raw material is initially stocked, then transported to machine 1 for processing, then to machine 2 and 3 , and finally, the product is inspected and stocked.

For many years (and even nowadays) this definition has led industrial production and service managers to believe that the improvement of particular operations directly affects the process enhancement, and as an outcome, the results of the whole organization. This interpretation reflects the lack of understanding of the Production Function Mechanism (PFM) originally proposed by Shingo in 1945, where both process and operation are viewed from two different perspectives, observed through an interrelated network in a cartesian, nonlinear plane. Another point of this approach is the mistaken assumption that improvements in optimal locations favor the global optimum, without taking into account the theory of constraints (TOC) proposed by Goldratt (1984). In Figure 1, a substantial productivity improvement in M1 machine (through automation, for example) without a proper observation of the production bottlenecks and balancing might incur additional losses in wait times, inventories, and reduced capital turnover, resulting in undesired effects.

In the context of the PFM, as shown in Figure 2, the structure of production is defined as a network of processes and operations along the intersecting axes. Shingo (1981) defines production as a "network of intersecting processes and operations" and considered its "discovery" as a milestone in the development of innovative production systems (SHINGO, 1988).Guinatto(1996) argues that the concept of production and the concept of the PFM, according to Shingo, is the same: "any production system is defined as a Production Function Mechanism", and the structure of this mechanism is a dynamic functional network of processes and operations combined in orthogonal flows".

While the process allows us to observe the flow of the work object (material or service) in time and space, operations allow us to visualize the flow of the work subject, which according to Antunes Jr. (1994), can be performed by workers(people) that represent "living work", and/or by machines and equipments, which are components of "dead work".

According to PFM, the improvement of a productive system $S_{p}$ must be conducted by focusing on process-related phenomena in time and space $P$, complemented later by the Operation Function $O_{j}$.

$$
S_{p}(t, \xi)=\left\{\left(P_{i}, O_{j}\right)\right\}, i=1,2 \ldots n ; j=1,2 \ldots, m
$$


The concept of Process is associated with the flow of materials in time and space and is composed of four distinct phenomena: processing, inspection, transportation, and waiting (or storage), the last three being characterized as activities that do not add value to the product.

Operations, on the other hand, represent the flow of workforce and machines in time and space and can be classified according to their usefulness and regularity, such as preparation, main operation (which may be essential or auxiliary), and clearances. Fundamentally, the useless operations should be eliminated.

Shingo (1986) argues that "it is the Process Function, in fact, that allows to achieve the main objectives of production, while the Operations play a supplementary role." Antunes Jr. (1994) reinforces this positioning, highlighting the importance of the process function in the improvement of the productive systems.

The equation 2.2 presents a counterpoint to the linear way in which the productive system is understood by many organizations. While equation 2.1 presented the process as a simple set of operations, the PFM approach suggests a network concept.

Shingo (1981) points out that before the study of the Toyota Production System, it is necessary to understand the Production Function Mechanism. The classic Figure 2 presents the view of Shingo's structure of production as anorthogonalnetwork of processes and operations.

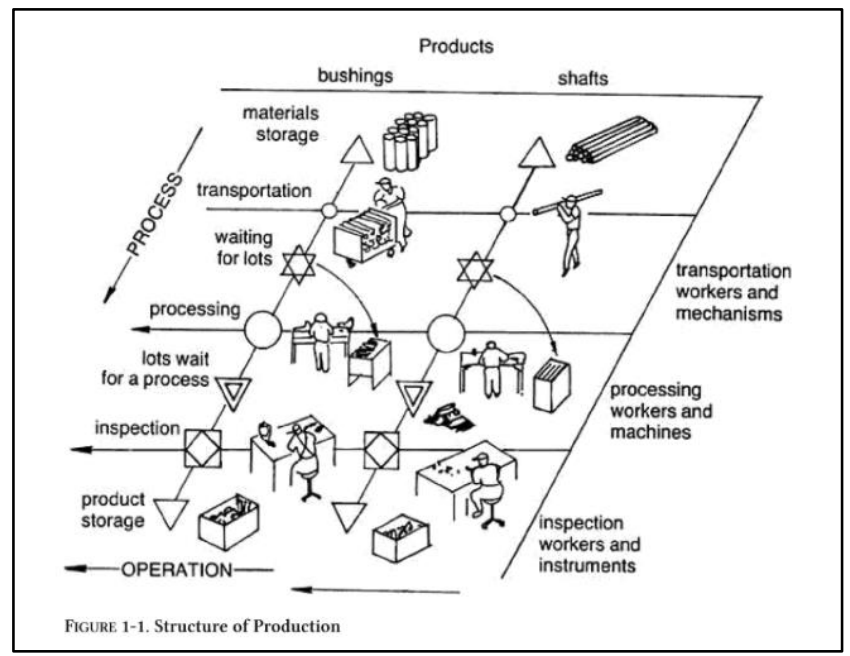

Figure 2: Structure of Production proposed by Shingo (1981; 1986; 1988).

The intersection points between the $\mathrm{X}$ (operations) and $\mathrm{Y}$ (processes) axes represent the encounters between the work object (raw material) and the work subject (people, machines, equipment) and any tentative of production optimization should pursue the reduction of the spaces between the intersection points, leaning to their complete elimination" (Guinato, 1996). In short, the optimization of the production system is the downsizing of the network structure, by reducing or eliminating activities that do not add value, which consequently reduces the number of intersections and spaces between them.

\subsection{The No-cost Principle and Total Waste Elimination}

The understanding ofthe Production Function Mechanism under an economic approach is closely linked with the knowledge of the guiding principles of Shingo and Ohno. This logic is related to the first oil crisis that occurred in 1973, which caused a drastic reduction of demand, and the organizations needed to readjust the models adopted at that time. 
Under the new market conditions, mass production and big batches no longer yielded the expected results, and the market showed signs of not absorbing the inefficiencies of the production processes. In this new scenario, where the capacity was greater than the demand and the market began to regulate prices, profit was then defined as the difference between the selling price and the cost.

Shingo (1981) highlights cost reduction as an alternative to maintaining or increasing profits as one of the most basic concepts of this logic. Ghinato (op cit.) stresses that the cost minimization is achieved by rationalizing the use of necessary resources, and the portion of resources used unnecessarily is essentially a "loss".According to Antunes Jr. (2019), it is important to note that the terms commonly used in Ohno and Shingo such as "no-cost", "zero stock", "total elimination" of losses are typical of the eastern culture, that wishes to enhance the culture of striving for perfection, that is, as much performance as possible towards the given goal.

The concept of work that adds value is also an integral part of the no-cost principle. This is characterized by the Process Function in the transformation of the raw material into a finished product, i.e. the processing itself, according to Ghinato (1996).

Understanding the PFM as a processes and operations network, considering the no-cost principle and total waste elimination concept, the focus on maximizing value-added work and minimizing non-value-added portions should guide the optimization of production systems.

\subsection{The Dialectic Process for Process Optimization}

Very often observed in contradictory arguments, as a result of the parties' inability to achieve a higher level of synthesis, a "halfway measure" solution is defined to reduce disadvantages on both sides, and only superficial results are observed.The dialectical process proposed by Shingo (1981) represents one of the bases for understanding the PFM and the TPS, as it proposes a higher level of synthesis as a way to solve the impasses between an argument (thesis) and a counterpoint (antithesis) to find a new way to execute a Process.

To empirically exemplify dialectical process, the following thesis can be set: In an ETO process (Engineered To Order) of an elevator manufacturing firm in Brazil, the production manager argues that for a lead time reduction, increasing traction machine inventories is required (traction machine is a bottleneck component, supplied by China with 20 weeks of transit time). In contrast, stocks are a waste and must be eliminated. Here, we have a contradictory condition that must be resolved through a higher level of synthesis.Ananalysismust thoroughly evaluate the Process Function, observing the flow of the work object in time and space, and later on, the Operations. In this example, since this component is sourced through outsourcing (without factory transformation) and, considering the traction machine is not part of the early stage of the elevator assembly process, a higher-level synthesis solution could be: adopt a new logistics model, shipping the traction machine directly to the customer from the supplier, while the other elevator components would already be under installation process at the customer's site. With that synthesis, machine orders would continue Just-In-Time, and elevator manufacturing and installation lead times would be reduced. Figure 3 provides a framework for the dialectic process proposed by Shingo.

The dialectics, as a mechanism for conflict resolutions, also influenced the thinking processes of TOC, since its foundations are observed in the Evaporation Clouds tool. 
In the context of capital circulation, the resolution of complex conflicts through the dialectical process proposed by Shingo is a fundamental condition for the improvement of production structures.

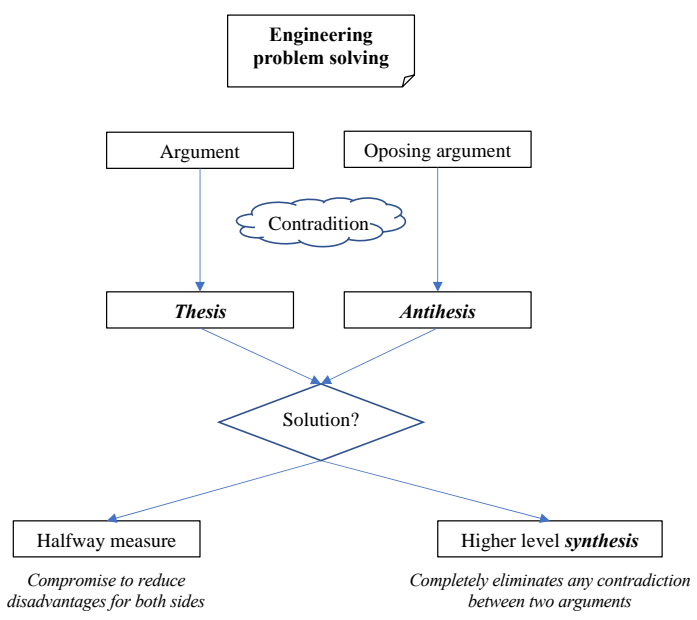

Figure 3: Elaborated by the author based on Dialectics proposed by Shingo.

\subsection{The Economic Bias of the Production Function Mechanism and the Toyota Production System}

Economics is a word used daily, but rarely understood, even by companies (OHNO, 1988). In the Toyota Production System, the economic aspects are thought in terms of two pillars: the reduction of the workforce and the reduction of costs sustained by the concepts of Autonomation and Just In Time, always seeking the total elimination of wastes (losses). The establishment of the TPS culture through the elimination of the seven major classes of waste (overproduction, waiting for transportation, processing, inventory, handling, and defective products) allowed Toyota to develop the most efficient production system known to date, highlighted by Ohno (op.cit) that the complete elimination of these wastes can increase operating efficiency by a wide margin.

The PFM proposed by Shingo is closely linked to the elimination of wastes, including waiting times. Such importance of the losses caused by waiting is represented in Ohno's response to Norman Bodeck, in his Preface to the Brazilian edition of the book Toyota Production System: in addition to the large-scale production of what Toyota was doing at that time: "Everything we are doing is to look at the timeline [...] and we are reducing that line by removing waste that doesn't add value".

Nakamura andPalombini (2011) argues that financial managers are devoting a significant amount of time and effort to manage capital turnover, balancing short-term achievements and demands. One of the metrics applied to working capital management is the Cash Conversion Cycle (CHONG-CHUO, 2018). This indicator measures the period in the number of days between the purchase of the raw material and the revenue from the finished product.

The understanding of production system optimization by eliminating the non-value-added phenomena and decreasing the orthogonal grid spaces (wait times) can be linked to the concept of the Capital Conversion Cycle. Although the economic bias of PFM and TPS are present in the literature, few articles have presented the direct connection between the reduction of lead time and capital circulation. The shorter CCC is, the more optimized the production structure of the organization is, and a better economic result will be verified as illustrated in Table 3, shown in the following section. 


\section{A PRACTICAL APPROACH OF THE PFM}

As a basis for a practical discussion of the Production Function Mechanism, a stainless-steel door manufacturing process at an Elevator industry was assessed. The firmisa multinational company with more than 70 years in Brazil.The sequence of assessed production phenomena is shown in Table 1 and Figure 4.

Table 1: Sequential phenomena observed in the production process.

\begin{tabular}{|c|l|}
\hline Phenomena & \multicolumn{1}{c|}{ Description } \\
\hline 0 & $\begin{array}{l}\text { Initial state: raw material stored atwarehouseDALG (441 0.9mm stainless steel } \\
\text { flat sheets). } \\
\text { Transport batch of raw material (0.9mm steel sheets) from the warehouse to the } \\
\text { manufacturing cell - CNC Trumpf Punch area. } \\
2\end{array}$ \\
3 & $\begin{array}{l}\text { Prepare batches of 0.9mm steel sheets in the machine (pre-processing). } \\
\text { Run drilling plan program at CNC terminal. } \\
\text { Process machining plan (machine period in operation, adding value to the product } \\
\text { being processed). } \\
\text { Waits for the batch to complete (work in progress stock). } \\
\text { Inspect the batch. } \\
\text { Transport batch to the cutting cell. }\end{array}$ \\
\hline
\end{tabular}

Considering the types of phenomena that are characteristic of $P_{1}$ (Transport), $P_{2}$ (Processing), $P_{3}$ (Inspection) and $P_{4}$ (Storage)processes, and also the sequence of operations listed above, it was evaluatedeach phenomena according to the PFM precepts:

- Raw material inventory is a typical storage process and is considered one of the seven waste classes proposed by Ohno and Shingo. In the PFM orthogonal network, this phenomenon has no intersection, once the work subject does not interact with the work object (which, in this example, is the raw material for the manufacturing of the door).

- A batch of $0.9 \mathrm{~mm}$ stainless steel sheets (work object) is transported manually by a production assistant (work subject). Thus, this phenomenon is an evident intersection in the network of processes and operations.

- The machine preparation is a typical operation. However, it does not represent a point of intersection.

- The CNC program processing for drilling plan execution is also a preparation operation. Like phenomenon 2, there is no intersection in the network.

- In this processing phenomenon, the CNC Punch machine (work subject) starts the machining operation on the steel sheets (work object). It is worth highlighting the example of the "dead" subject, since the work is performed by an automated machine, and not by humans.

- The batch completion wait time generates the stock-in-process for its completion, as well as inventory, and this represents a loss to the production process.

- The batch inspection process represents a point of intersection of the object and subject of the work (production operator), but without adding value to the product.

- Finally, the transportation of the batch to the production process sequence is a new intersection of the object and subject of the work. 
Improvement in production methods must start with Production Engineering, which is a way of thinking about how to make improvements, and efforts should then be directed primarily at day-to-day events and trivial problems instead of significant and fundamental gains (SHINGO, 1988). The production phenomena from the PFM perspective must be analytically observed through the intersections in the orthogonal network, where the work object (materials) and work subject meet.

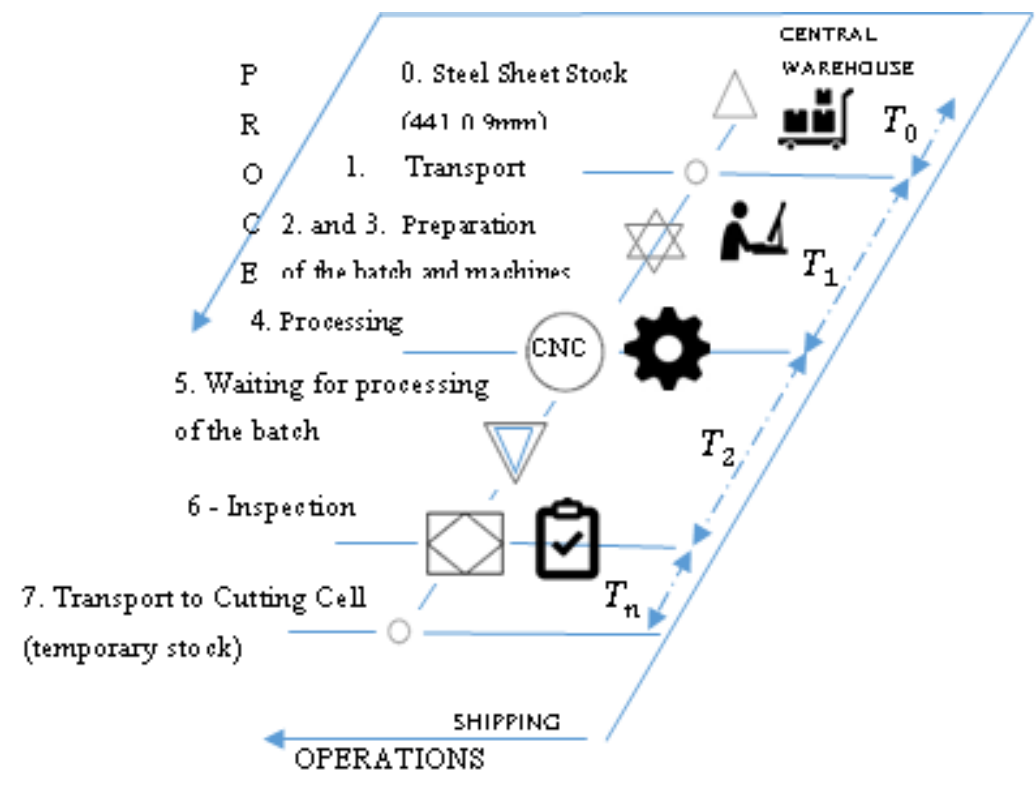

Figure 4: PFM adapted from Shingo $(1981 ; 1986 ; 1988)$. Elaborated by the author.

"When we seriously consider improving, the first step is to identify the problem". Shingo completes his famous quote by pointing out that"the real problem is thinking there are no problems." Every production system has opportunities to be improved or optimized. Being constructively dissatisfied with the current situation is an essential condition for developing an operational improvement process.

Based on Ghinato(1996), the analysis of the PFM is fundamental for the introduction of improvements in the production system, and the optimization of production should pursue the reduction of existing spaces between the PFM network intersection points, and, ultimately, the network downsizing, which means eliminating part of the operations or processes. This optimization approach is shown in Table 2 and must always focus on the Process Function as the main source of efficiency gain in a production system.

The findings of Shingo and Ohno refer to the economic bias of the production system. Behind the production theory, methods, and techniques proposed by these authors, the interest in maximizing the gains has always guided the Japanese production engineering. The literature has a scarcity regarding how the PFM contributes to the capital circulation optimization. Based on our literature review, Table 2 synthesize a 10-step process for improving the structure of production from the perspective of PFM and Scientific Thinking Mechanism (STM).

Table 2: 10-step process for improving the structure of production from the perspective of PFM and Scientific Thinking Mechanism (STM).

\begin{tabular}{|c|l|}
\hline Step & \multicolumn{1}{c|}{ Description } \\
\hline $\begin{array}{c}\text { Preliminary } \\
1\end{array}$ & $\begin{array}{l}\text { Classify the nature of the problem based on STM. } \\
\text { Mapping of the macro-layout and production structure initially found. }\end{array}$ \\
\hline
\end{tabular}




\begin{tabular}{|c|c|}
\hline 2 & $\begin{array}{l}\text { Characterization of the structure of production through a network of processes and } \\
\text { operations, observing the object and subject of work in time and space. }\end{array}$ \\
\hline 3 & Evaluation of lead time and process efficiency. \\
\hline 4 & $\begin{array}{l}\text { Analysis of the intersection points of the network (where object and work subjects } \\
\text { meet along the productive flow). }\end{array}$ \\
\hline 5 & Mapping the gaps between network phenomena, quantifying the time between them. \\
\hline 6 & Network optimization by focusing on Function Process (reduction or elimination). \\
\hline 7 & Improve the efficiency of operations. \\
\hline 8 & Lead time evaluation after layout, process, and operational improvements. \\
\hline 9 & $\begin{array}{l}\text { Measurement of the effect on the circulation of capital by calculating the Capital } \\
\text { Conversion Cycle (CCC). }\end{array}$ \\
\hline 10 & Evaluation of investments required. \\
\hline
\end{tabular}

Through the empirical example of this section, elapsed times $T_{i}$ are associated with each of the phenomena $i$. This analysis allows us to often look at immediate efficiency gains opportunities. Between the phenomena " 0 " and " 1 ", for example, it is possible to observe the raw material stocking time before entering the production process (storage cost), as well as the transportation time resulting from the network gap between phenomena " 1 " and " 2 " due to a possible inefficient factory macro lay-out. Also, theCNC setup times can be reduced, or ideally eliminated. In this line of reasoning, all phenomena are evaluated under the bias of rapid capital circulation, by reducing lead times.

\section{RESULTS AND DISCUSSIONS}

\subsection{Waits Reduction and its Effect on the Capital Conversion Cycle}

Table 3illustrates the performance of two product lines, A and B, by observing the sequenced steps of the production structure, as well as the total capital conversion cycle. The results suggest that due to the shortening of the lead time of product line B, especially the warehousing, setup, transportation, and inventory times per finished product, its efficiency is higher than A.

Table 3: Comparison between Capital Conversion Cycles in two product lines

\begin{tabular}{|c|c|c|c|}
\hline Event & $\begin{array}{l}\text { Type of } \\
\text { Function }\end{array}$ & $\begin{array}{l}\text { PRODUCT } \\
\text { LINE A }\end{array}$ & $\begin{array}{l}\text { PRODUCT } \\
\text { LINE B }\end{array}$ \\
\hline Raw Material Purchase & - & - & - \\
\hline$\triangle \quad$ Average Raw Material Storage Time & Process & 6.5 days & 5 days \\
\hline $\begin{array}{l}\text { Transportation time to production } \\
\text { cell }\end{array}$ & Process & 0.1 day & 0.05 day \\
\hline $\begin{array}{l}\text { Sum of the total waits for machine } \\
\text { preparation }\end{array}$ & Operation & 0.3 day & 0.2 day \\
\hline Processing & Process & 0.4 day & 0.4 day \\
\hline$\nabla \quad$ Batch completion wait & Process & 0.3 day & 0.3 day \\
\hline$\Rightarrow$ Inspection & Process & 0.05 day & 0.05 day \\
\hline Finished Product Stocking & Process & 2 days & 1 day \\
\hline Raw material payment schedule & & 20 days & 20 days \\
\hline Cash collection Deadline & & 30 days & 30 days \\
\hline CCC (Capital Conversion Cycle) & & 19.65 days & 17 days \\
\hline
\end{tabular}


Both product lines were unable to apply Just In Time to avoidrawmaterial inventories. The product line B was more efficient than A regarding this matter. An improvement in factory layout at B, for example, may have ensured a reduction in the transportation time of the raw material to the production cell. Reducing the machine setup via SMED has made the preparation stage of line B machines more efficient. Finally, the reduced end stocks of product line B and the rapid revenue generation from the sale of finished products have ensured better management performance of capital.

The Capital Conversion Cycle is represented by the sum in days of all stages involved in a production system, plus the time required for collecting the payment for the finished product sale minus the time required to pay the suppliers. It is not the purpose of the present study to deepen the understanding of the Capital Conversion Cycle in the financial perspective, but only to represent its importance to evaluate the production structure and its correlation with the lead time. However, to evaluate the CCC response due to the reduction of the times associated with process and operation functions, we propose a mathematical approach as follows:

$$
\operatorname{MinCCC}=\sum_{i=1}^{n} T f_{p(i)}+\sum_{i=j}^{m} T f_{o p(j)}+T_{r e c}-T_{p f}
$$

Where:

$$
\begin{aligned}
& T f_{p(i)} \quad=\text { Time of the Function Process } \mathrm{i}, \mathrm{i}=1,2 \ldots \mathrm{n} . \\
& T f_{o p(j)} \quad=\text { Time of the Function Operation } \mathrm{j}, \mathrm{j}=1,2, \ldots \mathrm{m} . \\
& T_{p f} \quad=\text { Time required to pay the supplier (constant). } \\
& T_{r e c} \quad=\text { Time required to collect money from the sales (constant). }
\end{aligned}
$$

According to (4.1) the Capital Conversion Cycle is reduced due to the reduction of processes and operations times in the production network. However, this reduction is not directly proportional since part of the constituting lead time phenomena were considered constants on this quantitative model. The data in Appendix I shows that even the reduction of inventory, transportation, waiting and inspection times by $10 \%$ for each period of analysis as a hypothetical simulation, CCC reduces non-proportionally, $4.71 \%$ in period 2 compared to period 1 and, $0.81 \%$ between the period 24 when compared to period 23. This is because the optimization of the production structure reaches a certain contribution limit for the CCC, as this indicator is also dependent on the conditions associated with the trade term agreements for payment of raw material purchases and also on the deadline for sales, represented here as 20 and 30 days, respectively.

F inally, in period 25 the mathematical model is forced to negate all waste times. In this scenario, CCC was 10.4 days, which is exactly the difference between the periods of the capital collection from the sale of the finished product and the payment of purchases of raw materials, plus the processing time only.

\section{CONCLUSIONS}

Despite having a profound influence on the development of the Toyota Production System, the Production Function Mechanism (PFM) proposed by Shingo is poorly referenced in the literature. In contrast, empirical researches associated with Kanban, JIT, VSM, and Lean havepresentedsignificantgrowthwhen compared to theoretical approaches.

This article aimed at recovering the fundamentals of the Production Function Mechanismandits economic impact on capital circulation. An empirical case was presented to illustrate how the PFMtheorycan affect the Cash Converting Cycle.Additionally, it was presented a10-step process for improving the structure of production from the PFM perspective 
and based on the Scientific Thinking Mechanism (STM).

The findings highlighted the relevance of Shigeo Shingo's contributions to Production Engineeringanddemonstrated how the reduction of waitsreach a non-directly proportional contribution for the Cash Converting Cyclereduction.

Understanding the Shingo's Production Function Mechanism as a prerequisite to understanding the Toyota Production System, many of the unsuccessful initiatives described on several papers about Lean and TPS implementation on industrial firms may berelated to a superficial approach. In that sense, this paper contributes to the literature and bringsbackseminal concepts to academics, and practitionersto consistently improve the structure of production based on those concepts.

This articleutilized the basic concept associated with the capital circulation; therefore, some variables may not have been considered that deepens these relations.

\section{REFERENCES}

1. ANTUNES Jr., J. A. V. (1994). O Mecanismo da Função de Produção: a Análise dos Sistemas Produtivos do Ponto-de-Vista de uma Rede de Processos e Operações. In: Production. Vol. 4. 33-46.

2. ANTUNES Jr., J. A. V. (1998). Em Direção a uma Teoria Geral do Processo na Administração da Produção; uma discussão sobre a possibilidade de unificação da teoria das restriç̃̃es e da teoria que sustenta a construção dos sistemas de produção com estoque zero. Porto Alegre. Tese de Doutorado em Administração, PPGA, Escola de Administração, Universidade Federal do Rio Grande do Sul.

3. Ch.V.Phani Krishna\& K.Bhargavi, "File Translator for Multi-Dimensional Design Model - A Smart Manufacturing Approach", International Journal of Computer Science and Engineering (IJCSE), Vol. 6, Issue 5,pp. 1-4

4. CHONG-CHUO, Chang. (2018). Cash conversion cycle and corporate performance: Global evidence. In: International Review of Economics and Finance. Vol. 56 568-581.

5. GHINATO, P. (1996). Sistema Toyota de Produção: mais do que simplesmente Just-in-Time. (Toyota Production System: More Than Just Just-in-Time.) Caxias do Sul: EDUCS.

6. GHINATO, P. (1998). Quality control methods: Towards modern approaches through well established principles. In: Total Quality Management. Vol. 9. 463-477.

7. V. Maharajasri \& D. Devamalar, "Characterization of Antibacterial, Anticancer Properties and Bioactive Compounds of Methanolic Leaf Extract Of Catharanthus roseus”, BEST: Journal of Humanities, Arts, Medicine and Sciences (BEST: JHAMS), Vol. 1, Issue 1, pp. 35-42

8. GOLDRATT, EM, Cox, J. (1984). The Goal. North River Press, Croton-on-Hudson, NY.

9. HINES, P., TAYLOR, D., WALSH, A. (2018). The lean journey: have we got it wrong? In: Total Quality Management \& Business Excellence.

10. HOPP, WJ \& SPEARMAN, ML (1996). Factory Physics. Boston: Irwin / McGraw-Hill. MONDEN, Y. (1984). Sistema Toyota de Produção. (Toyota Production System) São Paulo: IMAM.

11. T. Indira Rao \& Hongsandra Ramarao Nagendra, "The Role of Yogasanas and Pranayama Techniques in Correcting the Functional Disorders of Voice Production", IMPACT: International Journal of Research in Humanities, Arts and Literature (IMPACT: IJRHAL), Vol. 2, Issue 7, pp. 159-166 
12. KELLY, S.; HINES, P. (2019). Discreetly embedding the Shingo Principles of Enterprise Excellence at Abbott Diagnostics manufacturing facility in Longford Ireland. In: Total Quality Management \& Business Excellence. Vol. 30 1235-1256.

13. NAKAMURA, W.T, PALOMBINI, N.V.N. (2012). Key factors in working capital management in the Brazilian Market. In: Journal of Business Administration. Vol. 52.

14. OHNO, T. (1988). The Toyota production system: Beyond large scale production. Portland, OR: Productivity Press.

15. SHINGO, S. (1981) Study of Toyota Production System from an Industrial Engineering Viewpoint: Japan Management Association.

16. Dipanshu Sur, "Methimazole-Induced Hypothyroidism in Rats: Effect of Methimazole-Induced Cellular Damage on Heart, Lung and Ovary”, International Journal of Applied and Natural Sciences (IJANS), Vol. 3, Issue 4, pp. 21-28

17. SHINGO, S. (1986). Zero Quality Control. Cambridge: Productivity Press.

18. SHINGO, S. (1988). Non-stock Production: The Shingo System for Continuous Improvement. Cambridge: Productivity Press.

19. WOMACK, J. P.; JONES, D. T. \& ROOS, D. (1990). The machine that changed the world: How Lean production revolutionized the global car wars. New York: Rawson Associates.Appendix I-Cash Conversion Cycle Simulation

\begin{tabular}{|c|c|c|c|c|c|c|c|c|c|c|c|c|c|c|c|}
\hline \multirow[b]{3}{*}{ Sequence } & & \multirow[b]{3}{*}{ \# Days } & \multirow[b]{3}{*}{ Hours } & \multirow{2}{*}{\multicolumn{12}{|c|}{ Period }} \\
\hline & & & & & & & & & & & & & & & \\
\hline & & & & 1 & 2 & 3 & 4 & 5 & 6 & 7 & 8 & 9 & 10 & 11 & $\frac{12}{2}$ \\
\hline Raw material purchase & & 0 & 0 & 0,00 & 0,00 & 0,00 & 0,00 & 0,00 & 0,00 & 0,00 & 0,00 & 0,00 & 0,00 & 0,00 & 0,00 \\
\hline Average Raw Material Storage Time & Variable & 6,5 & 156 & 9360,00 & 8424,00 & 7581,60 & 6823,44 & 6141,10 & 5526,99 & 4974,29 & 4476,86 & 4029,17 & 3626,26 & 3263,63 & 2937,27 \\
\hline Transport time to production œall & Variable & 0,1 & 2,4 & 144,00 & 129,60 & 116,64 & 104,98 & 94,48 & 85,03 & 76,53 & 68,87 & 61,99 & 55,79 & 50,21 & 45,19 \\
\hline Sum of the total wait for machine preparation & Variable & 0,3 & 7,2 & 432,00 & 388,80 & 349,92 & 314,93 & 283,44 & 255,09 & 229,58 & 206,62 & 185,96 & 167,37 & 150,63 & 135,57 \\
\hline Procossing & Constant & 0,4 & 9,6 & 576,00 & 576,00 & 576,00 & 576,00 & 576,00 & 576,00 & 576,00 & 576,00 & 576,00 & 576,00 & 576,00 & 576,00 \\
\hline Batch completion wait & Variable & 0,3 & 7,2 & 432,00 & 388,80 & 349,92 & 314,93 & 283,44 & 255,09 & 229,58 & 206,62 & 185,96 & 167,37 & 150,63 & 135,57 \\
\hline Inspection & Variable & 0,05 & 1,2 & 72,00 & 64,80 & 58,32 & 52,49 & 47,24 & 42,52 & 38,26 & 34,44 & 30,99 & 27,89 & 25,10 & 22,59 \\
\hline Finished Product Stocking & Variable & 2 & 48 & 2880,00 & 2592,00 & 2332,80 & 2099,52 & 1889,57 & 1700,61 & 1530,55 & 1377,50 & 1239,75 & 1115,77 & 1004,19 & 903,77 \\
\hline Raw material payment schedule & Constant & -20 & -480 & $-28800,00$ & $-28800,00$ & $-28800,00$ & $-28800,00$ & $-28800,00$ & $-28800,00$ & $-28800,00$ & $-28800,00$ & $-28800,00$ & $-28800,00$ & $-28800,00$ & $-28800,00$ \\
\hline Cash collection Deadline & Constant & 30 & 720 & 43200,00 & 43200,00 & 43200,00 & 43200,00 & 43200,00 & 43200,00 & 43200,00 & 43200,00 & 43200,00 & 43200,00 & 43200,00 & 43200,00 \\
\hline CCC - Cash Converting Cycle & Variable & 19,65 & - & 19,65 & 18,73 & 17,89 & 17,14 & 16,47 & 15,86 & 15,32 & 14,82 & 14,38 & 13,98 & 13,63 & 13,30 \\
\hline Reduction $\%$ of CCC in each period & & - & - & & $4,71 \%$ & $4,45 \%$ & $4,19 \%$ & $3,93 \%$ & $3,69 \%$ & $3,44 \%$ & $3,21 \%$ & $2,98 \%$ & $2,77 \%$ & $2,56 \%$ & $2,37 \%$ \\
\hline
\end{tabular}

\begin{tabular}{rrrrrrrrrrrrr}
\hline $\mathbf{1 3}$ & $\mathbf{1 4}$ & $\mathbf{1 5}$ & $\mathbf{1 6}$ & $\mathbf{1 7}$ & $\mathbf{1 8}$ & $\mathbf{1 9}$ & $\mathbf{2 0}$ & $\mathbf{2 1}$ & $\mathbf{2 2}$ & $\mathbf{2 3}$ & $\mathbf{2 4}$ & $\mathbf{2 5}$ \\
\hline 0,00 & 0,00 & 0,00 & 0,00 & 0,00 & 0,00 & 0,00 & 0,00 & 0,00 & 0,00 & 0,00 & 0,00 & 0,00 \\
2643,54 & 2379,19 & 2141,27 & 1927,14 & 1734,43 & 1560,98 & 1404,89 & 1264,40 & 1137,96 & 1024,16 & 921,75 & 829,57 & 0,00 \\
40,67 & 36,60 & 32,94 & 29,65 & 26,68 & 24,02 & 21,61 & 19,45 & 17,51 & 15,76 & 14,18 & 12,76 & 0,00 \\
122,01 & 109,81 & 98,83 & 88,94 & 80,05 & 72,05 & 64,84 & 58,36 & 52,52 & 47,27 & 42,54 & 38,29 & 0,00 \\
576,00 & 576,00 & 576,00 & 576,00 & 576,00 & 576,00 & 576,00 & 576,00 & 576,00 & 576,00 & 576,00 & 576,00 & 576,00 \\
122,01 & 109,81 & 98,83 & 88,94 & 80,05 & 72,05 & 64,84 & 58,36 & 52,52 & 47,27 & 42,54 & 38,29 & 0,00 \\
20,33 & 18,30 & 16,47 & 14,82 & 13,34 & 12,01 & 10,81 & 9,73 & 8,75 & 7,88 & 7,09 & 6,38 & 0,00 \\
813,40 & 732,06 & 658,85 & 592,97 & 533,67 & 480,30 & 432,27 & 389,05 & 350,14 & 315,13 & 283,61 & 255,25 & 0,00 \\
$-28800,00$ & $-28800,00$ & $-28800,00$ & $-28800,00$ & $-28800,00$ & $-28800,00$ & $-28800,00$ & $-28800,00$ & $-28800,00$ & $-28800,00$ & $-28800,00$ & $-28800,00$ & $-28800,00$ \\
43200,00 & 43200,00 & 43200,00 & 43200,00 & 43200,00 & 43200,00 & 43200,00 & 43200,00 & 43200,00 & 43200,00 & 43200,00 & 43200,00 & 43200,00 \\
\hline 13,01 & 12,75 & 12,52 & 12,30 & 12,11 & 11,94 & 11,79 & 11,65 & 11,52 & 11,41 & 11,31 & 11,22 & 10,40 \\
\hline $2,18 \%$ & $2,01 \%$ & $1,84 \%$ & $1,69 \%$ & $1,55 \%$ & $1,41 \%$ & $1,29 \%$ & $1,18 \%$ & $1,07 \%$ & $0,98 \%$ & $0,89 \%$ & $0,81 \%$ & \\
\hline
\end{tabular}

